\title{
Electrolysis of $\mathrm{MgCl}_{2}$ with a top inserted anode and an $\mathrm{Mg}-\mathrm{Pb}$ cathode
}

\author{
M. GÜDEN, İ. KARAKAYA \\ Middle East Technical University, Department of Metallurgical Engineering, 06531, Ankara, Turkey
}

Received 15 August 1993; revised 14 January 1994

High energy consumption in the production of magnesium by molten salt electrolysis is mainly due to the recombination of magnesium and chlorine. The large interelectrode distance used, in conventional techniques, to reduce the extent of 'back reaction', results in a significant potential drop. A laboratory cell that enables the operation with smaller interelectrode distance and easy separation of electrode products has been used to study electrolytic magnesium production. The cell features a top inserted graphite anode and a $\mathrm{Mg}-\mathrm{Pb}$ alloy cathode at the bottom. Current efficiency and power consumption were determined at $690^{\circ} \mathrm{C}$ using a current density of $0.48 \mathrm{~A} \mathrm{~cm}^{-2}$. Experiments were performed to study the effects of $\mathrm{MgCl}_{2}$ concentration and anode-cathode distance (a.c.d.) on cell operation. Results indicated that an electrolyte containing $20 \% \mathrm{MgCl}_{2}$ (equiweight $\mathrm{NaCl}: \mathrm{KCl}$ and $1 \% \mathrm{NaF}$ ) with a $3 \mathrm{~cm}$ a.c.d. reduced the cell voltage to $3.72 \mathrm{~V}$. This value corresponds to an energy consumption of $11.3 \mathrm{kWh} \mathrm{kg}^{-1}$ including the refining of $\mathrm{Mg}-\mathrm{Pb}$ alloy produced at the cathode. This cell performance is more energy efficient compared to conventional magnesium cells.

\section{Introduction}

When magnesium is produced electrolytically from an anhydrous molten chloride mixture, the cl:rrent efficiency is typically in the range 80 to $90 \%$. Several investigators [1-3] concluded that the major cause of the loss of magnesium during electrolysis is the direct reaction of liquid magnesium on the surface of the electrolyte and in the interelectrode region with the chlorine gas (back reaction). Therefore, the separation of magnesium drops from chlorine bubbles has often been considered to be a very important factor in controlling the loss of magnesium $[4,5]$.

In this study, an alternative cell design has been tested for the effect of electrolyte composition and interelectrode distance on the current and energy efficiencies. The main idea was to minimize the extent of the rechlorination reaction by collecting magnesium metal at the bottom, while chlorine gas was evolved at the top from a graphite anode. Such a cell design, like Hall-Herault cells for aluminum production, would not only increase current efficiency, but also decrease anode-cathode distance (a.c.d.) and thereby lower the energy consumption:

The main difficulty in collecting magnesium at the bottom of the cell arises from the lower density of magnesium than the electrolyte. This difficulty may be avoided by making an alloy which is denser than the electrolyte. In this study lead $(\mathrm{Pb})$ was chosen as an alloying element to collect liquid magnesium at the bottom of the cell.

\section{Experimental details}

\subsection{Cell assembly}

The schematic drawing of the cell assembly is shown in Fig. 1. A $4 \mathrm{~cm}$ o.d. alumina crucible was used to hold the cell. This crucible was placed into a quartz cell vessel $(5.5 \mathrm{~cm}$ o.d.). The $65 \mathrm{~cm}$ long vessel was covered at the top by a Teflon O-ring seal. This cover had five holes on it, each provided with rubber O-rings to make possible the vertical movement of parts (graphite anode, steel cathode, thermocouple, argon inlet, gas outlet) before and after an experiment.

Being noble to chlorine, graphite was chosen as anode material. As can be seen in Fig. 1, the anode has two parts. The one with larger diameter $(2 \mathrm{~cm})$ was conical in shape. This made the surface area of the anode and the cathode the same $\left(4.15 \mathrm{~cm}^{2}\right)$. The upper part with smaller diameter $(7 \mathrm{~mm})$ extended out of the cell from the top.

The cathode assembly consisted of two parts. These were the electrode part and the stainless steel rod ( $2 \mathrm{~mm}$ diam.) used to connect the electrode to the source. The electode part, a stainless steel disc, was placed at the bottom of the cell during electrolysis. An alumina rim was constructed around it to prevent spilling of collected metal during an experiment and at the same time to confine the cathode surface to $4.15 \mathrm{~cm}^{2}$. The stainless steel rod was connected to the electrode at the lower end and extended out of the cell vessel from the top. An alumina insulator was used to cover this rod at the bottom (in the electrolyte) to prevent electrolysis on the surface of 


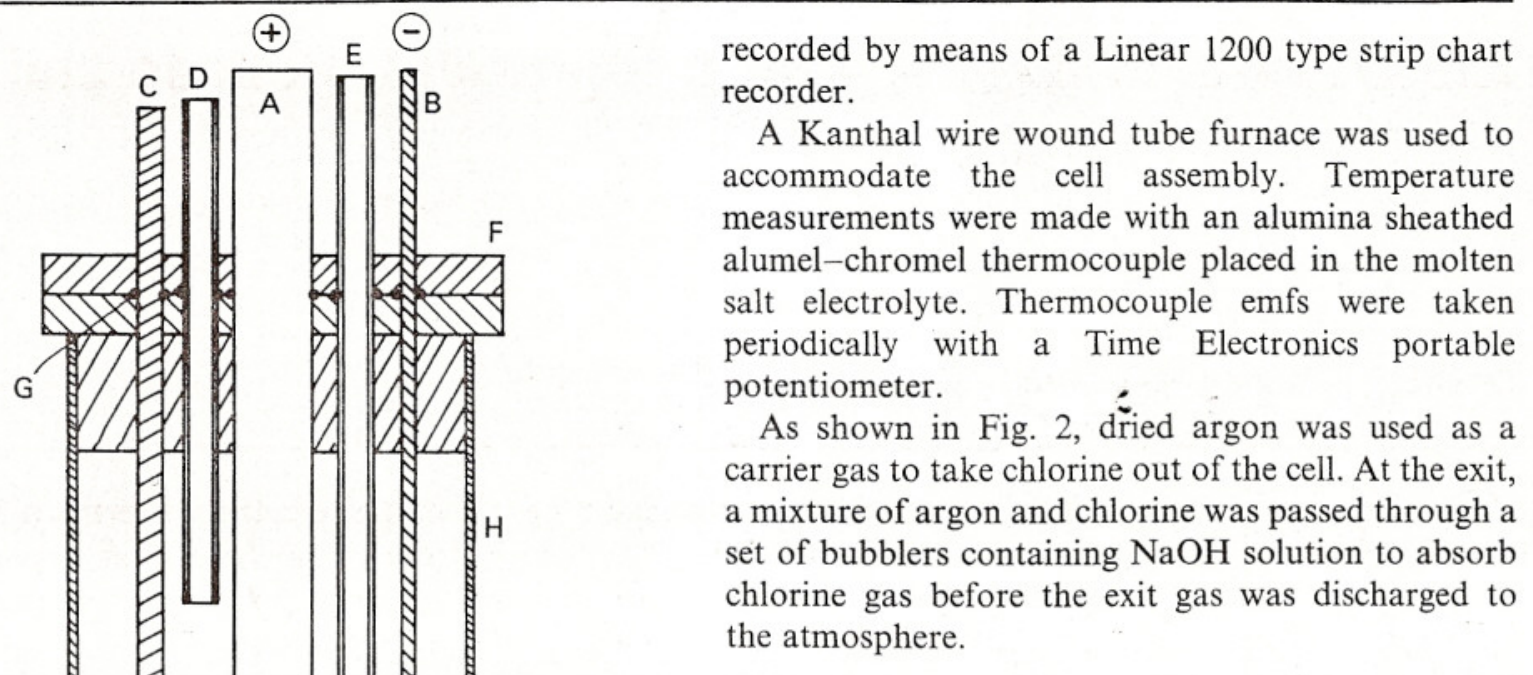

\section{Experimental procedure}

\subsection{Cell feed preparation}

Molten salt electrolytes containing equiweight $\mathrm{NaCl}: \mathrm{KCl}, 7$ to $20 \mathrm{wt} \% \mathrm{MgCl}_{2}$ and $1 \mathrm{wt} \% \mathrm{NaF}$, were used. From $\mathrm{MgCl}_{2}-\mathrm{NaCl}-\mathrm{KCl}$ ternary [1], the liquidus of the electrolyte with the above composition range is between 620 to $650^{\circ} \mathrm{C}$; enabling electrolysis to be carried out just above the melting point of magnesium $\left(651^{\circ} \mathrm{C}\right)$.

All the salts other than $\mathrm{MgCl}_{2}$ were reagent grade from Merck and they were dried in a Pyrex crucible at $250^{\circ} \mathrm{C}$ for $3 \mathrm{~h}$ before each experiment. Magnesium chloride (minimum 98\% $\mathrm{MgCl}_{2}, 1.5 \% \mathrm{H}_{2} \mathrm{O}$ ) was obtained from Aldrich Chemical Company. Appropriate amounts of $\mathrm{NH}_{4} \mathrm{Cl}$ (i.e. $25 \mathrm{~mol} \%$ more than $\mathrm{H}_{2} \mathrm{O}$ content of $\mathrm{MgCl}_{2}$ ) were added to the salt mixture to minimize the $\mathrm{MgO}$ sludge in the electrolyte [1]. The residual concentrations of oxide equivalent (oxide and/or hydroxide present) of the molten salt electrolyte samples were measured by back titration on selected samples. It was found that nominally pure $\mathrm{MgCl}_{2}$ salt samples contained not

Fig. 1. Cell assembly. Key: (A) graphite anode, (B) steel cathode, (C) thermocouple, (D) argon inlet, (E) chlorine outlet, (F) Teflon top, (G) rubber O-rings, (H) quartz cell vessel, (I) alumina crucible, $(\mathrm{K})$ alumina thermocouple cover, (L) alumina edge, (M) molten salt, $(\mathrm{N})$ cathode and $(\mathrm{O})$ alumina insulator for cathode lead

the rod. No protection against the corrosion of the stainless steel rod, by chlorine outside the electrolyte was necessary, because it was cathodic.

\subsection{Auxiliary apparatus}

A schematic drawing of the auxilliary apparatus is shown in Fig. 2. The d.c. power for electrolysis was provided by a Griffin \& George type rectifier (maximum: $5 \mathrm{~A}$ at $\div 30 \mathrm{~V}$ ) employing a variac. A standard-type ammeter, model ST8 was placed between the power supply and the cathode terminal. The cell voltage was measured using an Escort EDM 111A type multimeter. The changes in cell voltage during electrolysis at constant current were

\subsection{Cathode preparation}

The cathode material was electrolytic lead $(99.8 \%)$ containing $0.0004 \% \mathrm{Cu}$ and a minor amount of $\mathrm{Bi}$, at the beginning of an experiment. Cathode preparation involved the melting and casting of 10 to $20 \mathrm{~g}$ of electrolytic lead in the form of a disc with $2.3 \mathrm{~cm}$ diameter. This diameter was the same as the inner diameter of the steel disc used to hold the cathode. The surface of the cathode disc was mechanically cleaned before being placed into the cathode holder. At the beginning of each experiment a new lead cathode was prepared, weighed and placed on the steel disc with an alumina rim (cathode holder).

For experiment 6 , an $18 \% \mathrm{Mg}-82 \% \mathrm{~Pb}$ alloy was used as cathode. This alloy was prepared in a graphite crucible under argon atmosphere at $700^{\circ} \mathrm{C}$. This temperature was well above the melting point of the alloy (melting point of $\mathrm{Mg}-\mathrm{Pb}$ alloy with above 


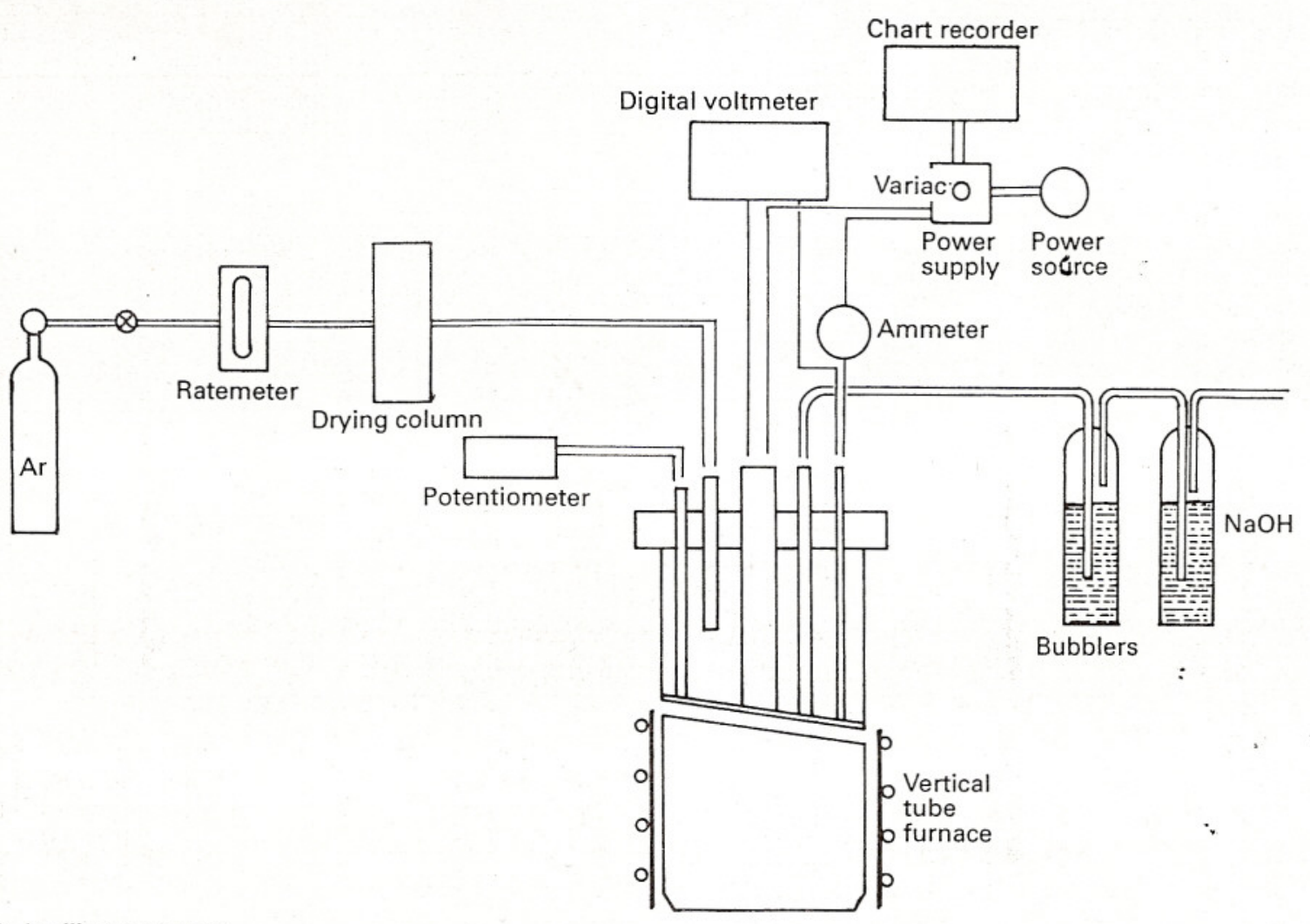

Fig. 2. Auxiliary apparatus.

composition is about $480^{\circ} \mathrm{C}$ [6]). Thus, a homogenous $\mathrm{Mg}-\mathrm{Pb}$ alloy was prepared. The same procedure was followed in the cathode preparation for the refining experiment.

\subsection{Cell operation}

The cell containing 50 to $100 \mathrm{~g}$ of electrolyte, together with an appropriate amount of $\mathrm{NH}_{4} \mathrm{Cl}$ was placed into the vessel. The cover, accommodating the electrode assembly etc., was then placed over the vessel (see Fig. 1). The heating process was started after all the connections to the auxiliary apparatus were completed. A procedure similar to that of Belton and Rao [7] was followed during heating. The cell vessel was heated slowly up to about $400^{\circ} \mathrm{C}$ under continous flow of argon gas. During this operation, any excess $\mathrm{H}_{2} \mathrm{O}$ and $\mathrm{NH}_{4} \mathrm{Cl}$ vapour were carried out of the cell vessel. Evaporation of $\mathrm{NH}_{4} \mathrm{Cl}$ was continued until about $600^{\circ} \mathrm{C}$. The electrolyte and the cathode material became molten when the temperature reached about 680 to $690^{\circ} \mathrm{C}$. The cell vessel temperature was allowed to stabilize at about $690^{\circ} \mathrm{C}$. During this time electrodes and thermocouple were lowered and immersed into the electrolyte. The electrodes were then connected to the d.c. power supply and electrolysis started. :-

A current density of about $0.48 \mathrm{~A} \mathrm{~cm}^{-2}$ was used to simulate industrial conditions [8]. The current was switched off after a typical electrolysis period of 30 to $60 \mathrm{~min}$. At the end of each experiment, the cathode, a $\mathrm{Mg}-\mathrm{Pb}$ alloy, was removed from the steel disc, weighed and chemically analysed.

In addition, one refining experiment was performed to compliment the electrolysis studies. A similar procedure was followed for this experiment. After a certain period of electrolysis, electrodes were switched, in such a way that cathode was made anode and anode was made cathode. Thus, $\mathrm{Mg}-\mathrm{Pb}$ alloy was the anode subjected to the refining process. As a result of electrorefining pure magnesium globules were collected at the graphite cathode and floated over the surface of the electrolyte. After a certain period of refining, the cell was cooled and refined magnesium globules were collected, weighed and chemically analysed for impurities.

\subsection{Chemical analyses}

The chemical analyses were made by an atomic absorption spectrophotometer (Perkin-Elmer model 1230 ) and by a flame photometer (Jemway model PFP7) to determine: (i) the weight of magnesium deposited on the lead cathode after electrolysis, and (ii) the purity of magnesium metal collected after refining.

\section{Results and discussion}

Full details of the experimental results can be found elsewhere [9]. They are summarized in Table 1.

\subsection{Determination of current efficiency and energy consumption}

Current efficiency was determined by two methods. At the lower $\mathrm{MgCl}_{2}$ concentrations, the current efficiency was determined by using the results of atomic 


\begin{tabular}{|c|c|c|c|c|c|c|c|c|}
\hline & \multicolumn{8}{|c|}{ Experiment } \\
\hline & 1 & 2 & 3 & 4 & 5 & 6 & 7 & 8 \\
\hline $\mathrm{ACD} / \mathrm{cm}$ & 1 & 2 & 2 & 2 & 2.5 & $\leqslant 3$ & 3.5 & 4.25 \\
\hline Av. temperature $/{ }^{\circ} \mathrm{C}$ & 683 & 690 & 688 & 685 & 690 & 690 & 683 & 690 \\
\hline Current density $/ \mathrm{A} \mathrm{cm}^{-2}$ & 0.48 & 0.48 & 0.48 & 0.48 & 0.48 & 0.48 & 0.48 & 0.48 \\
\hline Electrolysis duration/min & 30 & 45 & 30 & 45 & 30 & 60 & 30 & 35 \\
\hline wt $\% \mathrm{MgCl}_{2}$ & 20 & 20 & 15 & 7 & 20 & 20 & 20 & 20 \\
\hline Av. cell voltage/V & 3.36 & 3.5 & 3.42 & 3.37 & 3.65 & 3.72 & 3.91 & 4.12 \\
\hline Mg deposited/g & 0.326 & 0.557 & 0.325 & 0.275 & 0.382 & 0.81 & 0.42 & 0.497 \\
\hline Current efficiency $/ \%$ & 72 & 82 & 72 & 40.5 & 84.5 & 89.5 & 93 & 94 \\
\hline Energy efficiency $/ \%$ & 56 & 61 & 55 & 31.5 & 60 & 63 & 62 & 59.5 \\
\hline Energy consumption $/ \mathrm{kWh} \mathrm{kg}^{-1}$ & 10.3 & 9.4 & 10.5 & 18.4 & 9.5 & 9.2 & 9.3 & 9.7 \\
\hline
\end{tabular}

absorption spectrophotometer, since $\mathrm{K}$ and $\mathrm{Na}$ may codeposit during electrolysis. At higher $\mathrm{MgCl}_{2}$ concentrations, the weight change of the alloy (cathode) during electrolysis and chemical analysis of the alloy (cathode) by the atomic absorption technique were used. The difference between the two methods was at most $3 \%$. The percentage current efficiency (CE) was calculated from

$$
\mathrm{CE}=\frac{W_{\mathrm{Mg}}}{W_{\mathrm{Th}}} \times 100
$$

where $W_{\mathrm{Th}}$ is the theoretical weight of magnesium deposited.

The energy consumption (EC) per kilogram of magnesium was calculated from

$$
\mathrm{EC}=\frac{100 E_{\mathrm{n}}}{0.4534 \times \mathrm{CE}}
$$

where $E_{\mathrm{n}}$ is the net cell voltage, that is the difference between the applied voltage across the poles, $E$, and the voltage drop along the electrode leads $\left(E_{\mathrm{a}-\mathrm{c}}\right)$. This net cell voltage was determined by subtracting the voltage drop measured across shorted electrodes, from the operating cell voltage. For the cell assembly used in this study $E_{\mathrm{a}-\mathrm{c}}$ was found to be $1.03 \mathrm{~V}$ at a current density of $0.48 \mathrm{~A} \mathrm{~cm}^{-2}$ and a temperature of $690^{\circ} \mathrm{C}$. The value of 0.4534 is the electrochemical equivalent for $\mathrm{Mg}$ in $\mathrm{g} \mathrm{A}^{-1} \mathrm{~h}^{-1}$.

\subsection{Effect of $\mathrm{MgCl}_{2}$ concentration}

The results from experiments involving the effect of $\mathrm{MgCl}_{2}$ concentration on the cell operation can be seen in Fig. 3. These experiments were designed to see, if $\mathrm{MgCl}_{2}$ concentrations similar to those used commercially could be used with this assembly.

Figure 3(a) shows the variation of net cell voltage, $E_{\mathrm{n}}$, with $\mathrm{MgCl}_{2}$ concentration. An increase in $\mathrm{MgCl}_{2}$ concentration from 7 to $20 \mathrm{wt} \%$ increased the net cell voltage by $0.13 \mathrm{eV}$. It may be assumed that the increase of net cell voltage with increasing $\mathrm{MgCl}_{2}$ concentration, in the $\mathrm{MgCl}_{2}-\mathrm{NaCl}-\mathrm{KCl}$ electrolyte, is caused by the relative decrease in concentration of $\mathrm{Na}^{+}$and $\mathrm{K}^{+}$ions. It should be noted that $\mathrm{MgCl}_{2}$ concentrations decreased as the electrolysis proceeded, since the present cell design did not permit continuous addition of $\mathrm{MgCl}_{2}$ to the electrolyte. But this change was in: the range of 2 or $3 \mathrm{wt} \%$ depending on the weight of the starting electrolyte and the electrolysis duration. .

Figure 3(b) indicates that the current efficiency increased with increasing $\mathrm{MgCl}_{2}$. concentration. Within the $\mathrm{MgCl}_{2}$ composition range covered in this study, an electrolyte composition of $20 \mathrm{wt} \% \mathrm{MgCl}_{2}$ with equiweight $\mathrm{NaCl}: \mathrm{KCl}$ was found to be optimum. The effect of $\mathrm{MgCl}_{2}$ concentration on the current efficiency has been widely studied [10-12]. At $0.5 \mathrm{~A} \mathrm{~cm}^{-2}$ current density, Zhurin [10], showed that current efficiency of magnesium decreased strongly, and sodium or potassium deposited with magnesium if the $\mathrm{MgCl}_{2}$ content in the electrolyte was lower than $7 \mathrm{wt} \%$. This is in agreement with Fig. 3(b). Zhurin concluded that the $\mathrm{MgCl}_{2}$ concentration should not exceed 15 to $18 \mathrm{wt} \%$. Muzhzhavlev [11], showed experimentally that the optimum $\mathrm{MgCl}_{2}$ concentration is 15 to $20 \mathrm{wt} \%$. The marked increase in current efficiency with $\mathrm{MgCl}_{2}$ concentration (see Fig. 3(b)) may be attributed (in addition to decrease in sodium and potassium codeposition) to decreasing chlorine solubility with increasing $\mathrm{MgCl}_{2}$ levels. Thus, the extent of back reaction may be reduced. Muzhzhavlev [12], showed experimentally that chlorine solubility decreases from $1.5 \times 10^{-7}$ to $1.1 \times 10^{-7} \mathrm{~mol} \mathrm{~cm}^{-3}$ with an increase of 13 to $20.3 \mathrm{MgCl}_{2}$ wt \%.

Variation of energy consumption with $\mathrm{MgCl}_{2}$ concentration is shown in Fig. 3(c). This figure illustrates the optimum content of $\mathrm{MgCl}_{2}$ as approximately $20 \mathrm{wt} \%$ (in fact this reduced to about $17 \%$ after electrolysis) without taking into account the sludge formation and $\mathrm{MgCl}_{2}$ evaporation. This is in agreement with Zhurin [10] and Muzhzhavlev [12]. Higher $\mathrm{MgCl}_{2}$ concentrations were not studied, because of increasing undesirable effects like sludge formation and $\mathrm{MgCl}_{2}$ evaporation.

\subsection{Effect of anode-cathode distance}

The effect of anode-cathode distance (a.c.d.) on cell operation was studied with an electrolyte composition of $20 \mathrm{wt} \% \mathrm{MgCl}_{2}$, equiweight $\mathrm{NaCl}-\mathrm{KCl}$ 

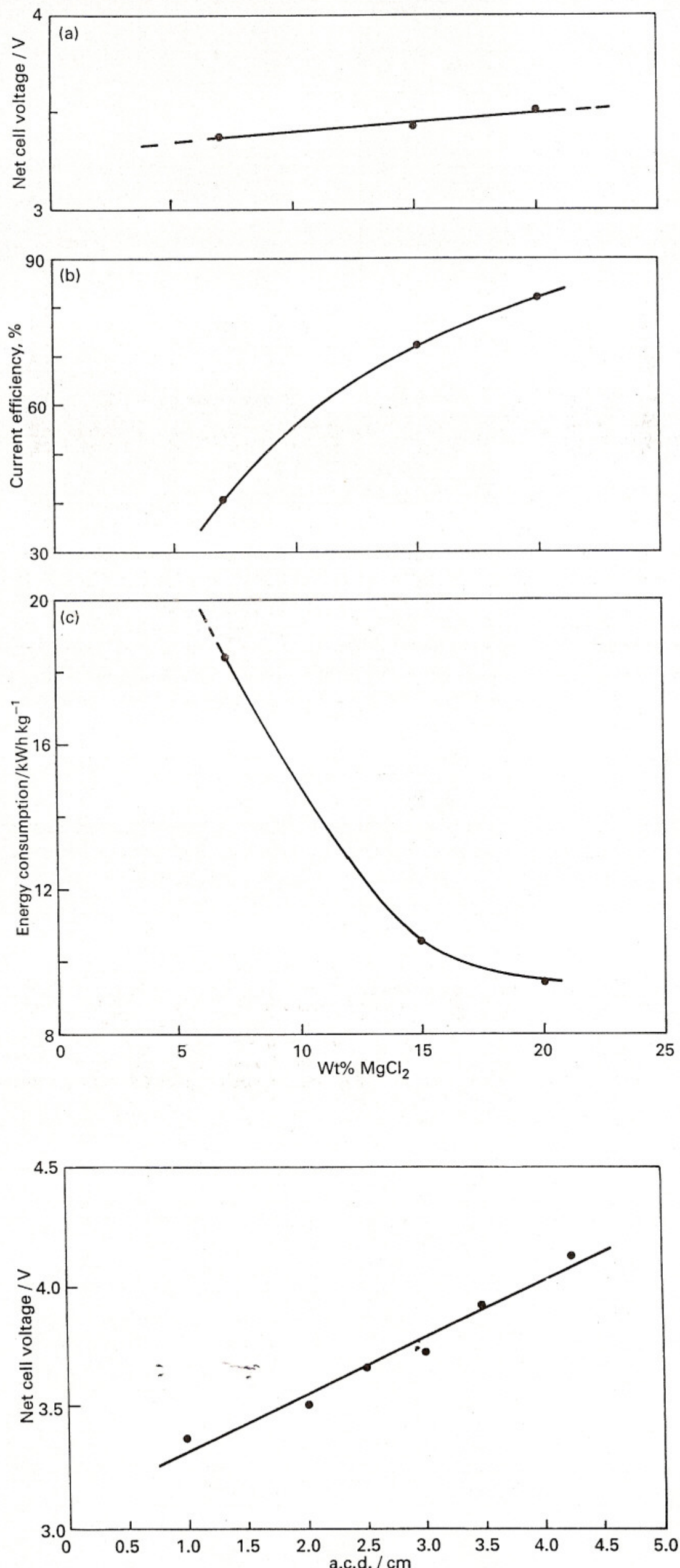

Fig. 4. Variation of net cell voltage with a.c.d. Current density: $0.48 \mathrm{~A} \mathrm{~cm}^{-2}$; current: $2.0 \mathrm{~A}$; temperature: $683-690^{\circ} \mathrm{C}$; wt $\% \mathrm{MgCl}_{2}: 20.0$.
Fig. 3. Effect of $\mathrm{MgCl}_{2}$ concentration on cell operation. Experimental conditions: a.c.d. $=2 \mathrm{~cm}, \quad$ c.d. $=0.48 \mathrm{~A} \mathrm{~cm}^{-2}, \quad T=$ $685-690^{\circ}$ C. (a) Net cell voltage, (b) current efficiency, (c) energy consumption. 


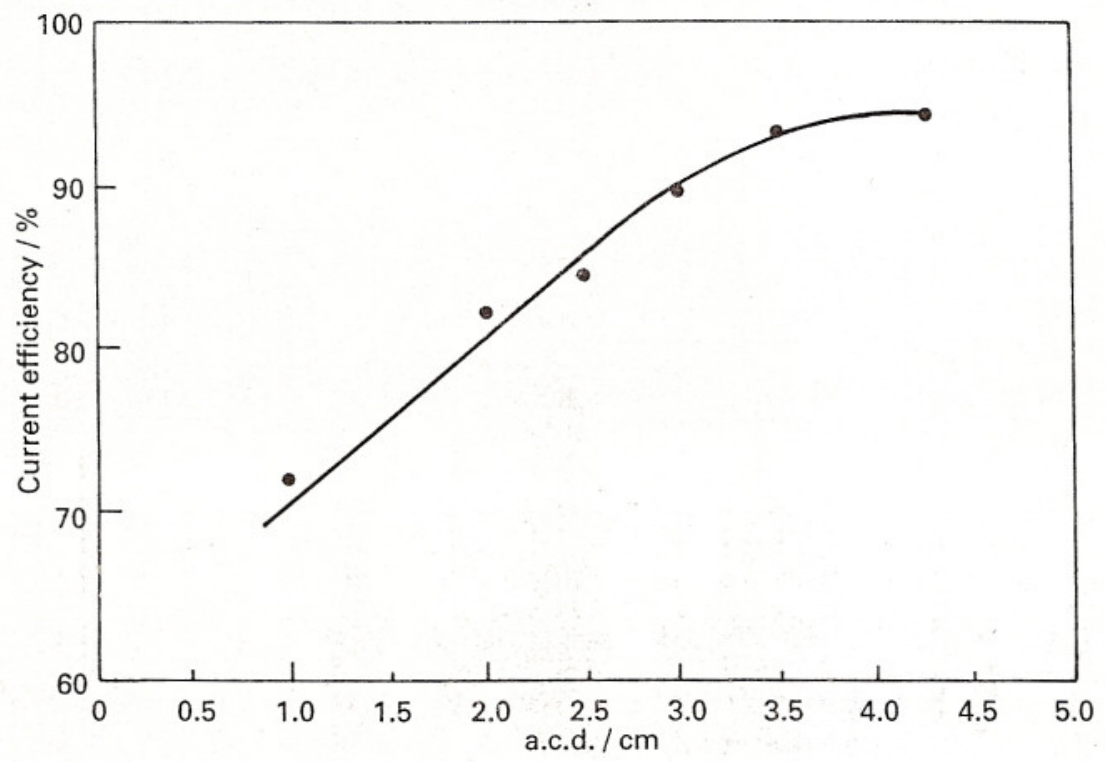

Fig. 5. Effect of a.c.d. on the current efficiency of the cell. Current density: $0.48 \mathrm{~A} \mathrm{~cm}^{-2}$; cur$\mathrm{MgCl}_{2}: 20.0$. : and $1 \mathrm{wt} \%$ NaF. Constant current density, $0.48 \mathrm{~A} \mathrm{~cm}^{-2}$, and a temperature of about $690^{\circ} \mathrm{C}$, were used. The results are presented in Figs 4, 5 and 6.

Figure 4 shows that the net cell voltage increased with increasing a.c.d. and the relation was almost linear due to ohmic effects. The equation of the linear variation of the net cell voltage, $E_{\mathrm{n}}$, with a.c.d., $X$, is

$$
E_{\mathrm{n}}(\mathrm{V})=3.068+0.237 X(\mathrm{~cm})
$$

Using $0.48 \mathrm{~A} \mathrm{~cm}^{-2}$ current density and $4.15 \mathrm{~cm}^{2}$ electrode area, the specific conductivity of the electrolyte is $2.02 \Omega^{-1} \mathrm{~cm}^{-1}$ at the operating temperature of $690^{\circ} \mathrm{C}$. This value is very close to $1.920 \Omega^{-1} \mathrm{~cm}^{-1}$ specific conductivity measured at $700^{\circ} \mathrm{C}$ [1]. The difference between these values may arise from the presence of chlorine in the system, the change in electrolyte composition and the polarization of the electrolyte during electrolysis.

The effect of a.c.d. on current efficiency is shown in Fig. 5. Current efficiency increased rapidly up to $3 \mathrm{~cm}$ a.c.d. Beyond $3.5 \mathrm{~cm}$ a.c.d., current efficiency tended to flatten out.

The variation of energy consumption with a.c.d. is illustrated in Fig. 6. As the a.c.d. increased the energy consumption first decreased and then increased.
Therefore, energy consumption can be minimized when the a.c.d. is $3 \mathrm{~cm}$. Between 1 to $3 \mathrm{~cm}$ a.c.d. energy consumption decreased from 10.3 to $9.2 \mathrm{kWh}$ $\mathrm{kg}^{-1}$, since the favourable effect of the rapidly increasing current efficiency was stronger than the adverse effect of the increasing voltage drop in the electrolyte. After $3 \mathrm{~cm}$ a.c.d. the current efficiency underwent no significant change, while the voltage drop in the electrolyte increased proportionally to the a.c.d.

\subsection{Refining of magnesium}

The above data are for the first step of the new design only. In order to compare present application with commercial cells, energy consumption to produce pure magnesium must be determined. Therefore, energy consumption in the refining process (refining of $\mathrm{Mg}-\mathrm{Pb}$ alloy) must be known. For this purpose one experiment was performed. This experiment was conducted with $17.0 \mathrm{wt} \% \mathrm{MgCl}_{2}$ at $1 \mathrm{~cm}$ a.c.d. with a prealloyed cathode, $23 \% \mathrm{Mg}-77 \% \mathrm{~Pb}$. A high current efficiency, about $97 \%$, and an energy consumption of $2.1 \mathrm{kWh} \mathrm{kg}^{-1}$ were obtained. If this value is added to the lowest energy consumption

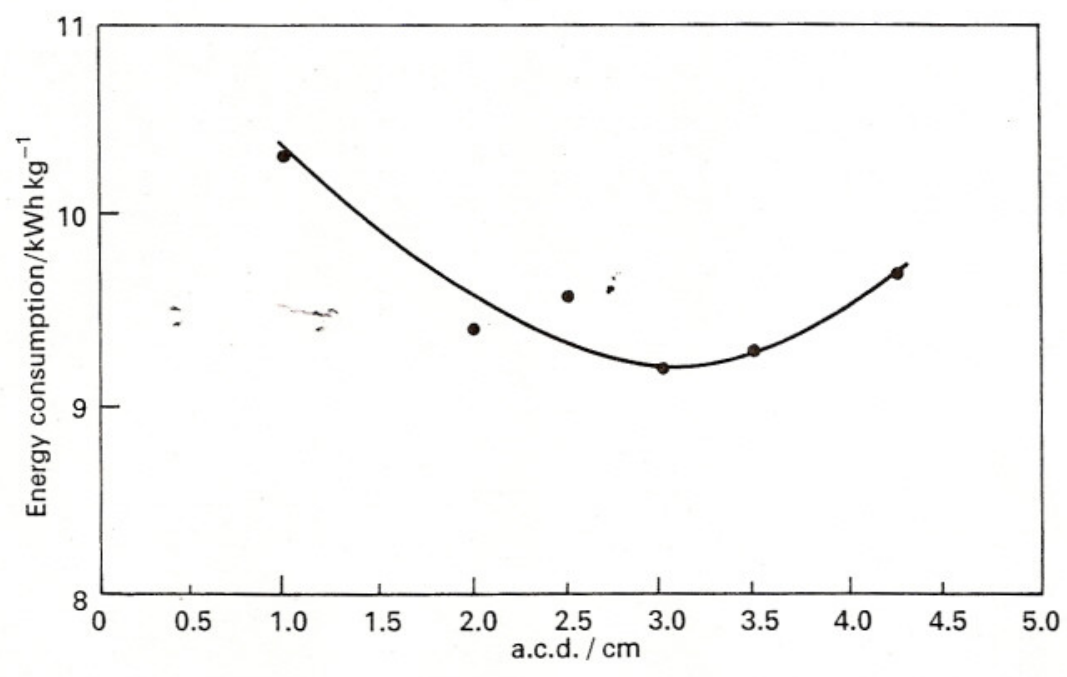

Fig. 6. Effect of a.c.d. on the energy consumption of the cell. Current density: $0.48 \mathrm{~A} \mathrm{~cm}^{-2}$; current: $2.0 \mathrm{~A}$; temperature: $683-690^{\circ} \mathrm{C}$; wt $\% \mathrm{MgCl}_{2}: 20.0$. 
value in the electrolysis experiments, at $3 \mathrm{~cm}$ a.c.d., 20 wt $\% \mathrm{MgCl}_{2}$, the total energy consumption becomes $11.3 \mathrm{kWh} \mathrm{kg}^{-1}$, excluding the energy consumption over the electrode leads.

Chemical analyses by atomic absorption and flame photometry showed that the impurity level of refined magnesium metal was similar to the purity achieved in present cells: $\% \mathrm{Na}<0.025, \% \mathrm{~K} \ll 0.025, \% \mathrm{Fe}=$ 0.038 and lead was not detectable. The small iron content in the refined magnesium may be attributed to contamination from the steel cathode material.

\section{Conclusions}

The primary objective of this experimental program was to reduce the extent of back reaction in magnesium electrolysis by using a cell design effecting an easy separation of chlorine from magnesium. This was accomplished by using a $\mathrm{Mg}-\mathrm{Pb}$ cathode and a top feeding anode. Impure magnesium was subjected to refining to obtain pure electrolytic grade magnesium.

Operation of the cell without a ceramic semiwall partition between the two electrodes enabled electrolysis at lower voltages with higher energy efficiencies. The present technique merits further attention to explore the compromise between energy and installation costs. In addition, the following conclusions are drawn from the present work:

(i) Cell voltage increases with increasing $\mathrm{MgCl}_{2}$ concentration and a.c.d. The increase is caused by decreasing conductivity in the case of increasing $\mathrm{MgCl}_{2}$ concentration and by increasing ohmic resistance with increasing a.c.d. (ii) The current efficiency shows a marked dependence on the $\mathrm{MgCl}_{2}$ concentration and a.c.d. It increases with both increasing $\mathrm{MgCl}_{2}$ concentration and a.c.d. This increase was explained as the results of decreasing sodium and potassium codeposition and a decrease in chlorine solubility with increasing $\mathrm{MgCl}_{2}$ concentration.

(iii) Energy consumption can be minimized when $3 \mathrm{~cm}$ a.c.d. is used with $20 \% \mathrm{MgCl}_{2} \quad 0.48 \mathrm{~A} \mathrm{~cm}^{-2}$ current density and about $690^{\circ} \mathrm{C}$ temperature.

\section{References}

[1] Kh. L. Strelets, Electrolytic Production of Magnesium, US Department of Commerce (1977).

[2] O. A. Lebedev, Soviet J. Non-Ferrous Metals 25 (1984) 52.

[3] O. A. Lebedev, K. D. Muzhzhavlev, A. N. Tatakin, O. N. Droyyaeva and V. P. Korzun, Tsvetnye Metally (1971) 44.

[4] E. Aarebrot, R. E. Andresen, T. Ostvold and H. A. Oye, Metall. 32 (1978) 41.

[5] E. A. Ukshe, G. V. Polyakova and G. A. Medvetskaya, $Z h$. Priklad. Khim. 33 (1960) 2279.

[6] M. Hanson, 'Constitution of Binary Alloys', McGráw Hill. New York (1958)

[7] G. R. Belton and Y. K. Rao, Trans. Metall. Soc. AIME 245 (1969) 2189

[8] A. Hafeez, 'Extraction of Magnesium in Gas Lift Electrolytic Cells', MSc thesis, McGill University, Montreal (1979).

[9] M. Guden, 'Electrolysis of $\mathrm{MgCl}_{2}$ with a Top Inserted Anode and a $\mathrm{Mg}-\mathrm{Pb}$ Cathode', MSc thesis, Middle East Technical University, Ankara (1992).

[10] A. I. Zhurin and O. G. Desyatnikov, Trudy Leningradskogo Politekhnicheskogo Instituta im M.I. Kalimina 1 (1946).

[11] K. D. Muzhzhavlev, G. V. Olyyuinin, T. S. Sheka and V. P. Sheka, Tsvetrye Metally 39 (1965) 62.

[12] K. D. Muzhzhavlev and O. A. Lebedev, Soviet J. NonFerrous Metals 10 (1970) 43. 